\title{
Detection of chlorine in tap water using a metal gold electrode Suw Young Ly ${ }^{\star}$ and Sung Hoon Choa ${ }^{1}$ \\ Biosensor Research Institute, Seoul National University of Science and Technology, Seoul, Korea ${ }^{1}$ NIT Engineering Department, Seoul National University of Science and Technology, Seoul, Korea (Received April 4, 2011; Accepted May 12, 2011)
}

\section{금속 $\mathrm{Au}$ 전극을 이용한 먹는 물 속 염소 이온 검출 \\ 이수영ᄎ · 좌성훈}

국립 서울 과학기술 대학교 바이오센서 연구소

(2011. 4. 4. 접수, 2011. 5. 12. 승인)

\begin{abstract}
요 약: 카본나노튜브 전극과 금 전극을 사용한 $\mathrm{Cl}(\mathrm{I})$ 이온의 전압전류 분석법을 비교 연구하였다. 금 전 극이 카본나노튜브 전극보다 $\mathrm{Cl}(\mathrm{I})$ 이온에 민감하게 반응함을 보였다. 위 조건에서 금 전극의 순환 전압 전류법과 벗김 전압 전류법의 최적 조건을 실험한 결과 $6.5 \mu \mathrm{g} / \mathrm{L} \mathrm{Cl}(\mathrm{I})$ 이온의 검출한계에 도달 하였다. 최적의 조건에서 기존에 상용되는 $\mathrm{Cl}$ 이온 미터와 먹는 물 속의 $\mathrm{Cl}(\mathrm{I})$ 이온 농도를 비교한 결과 보다 민감 하게 반응하였다.
\end{abstract}

\begin{abstract}
Voltammetric analysis of $\mathrm{Cl}(\mathrm{I})$ ion was performed using a metal gold ( $\mathrm{Au}$ ) electrode (AE) and a carbon nanotube electrode (CNTE). After the examination, the AE was found to have more sensitively detected $\mathrm{Cl}(\mathrm{I})$ than CNTE. The optimum analytical conditions for the cyclic voltammetry (CV) and the square wave (SW) stripping voltammetry were performed using AE. The detection limit of $6.5 \mu \mathrm{g} / \mathrm{L} \mathrm{Cl(I)} \mathrm{was} \mathrm{attained.}$ The developed techniques were compared with the common $\mathrm{Cl}$ meter and applied to water systems.
\end{abstract}

Key words: $\mathrm{Cl}$, Tap water, voltammetry, detection

\section{Introduction}

Chlorine is a toxic gas. As such, its precise detection in the environment is very important. ${ }^{1}$ Chloride ion sensing is especially used to biological field such as clinical diagnosis, environmental monitoring and industrial processing systems. ${ }^{2}$ Here can be used for sterilization and disinfection of waters controling, and as a bleaching agent in the textile and paper industry. ${ }^{3}$ Chlorine dioxide readily dissolves in water to form a solution that is biocidal to a wide range of microorganisms. ${ }^{4}$ In this process, various anions such as chloride, chlorate, and perchlorate are formed. ${ }^{3}$ These anions are considered dangerous to public health even at low levels. ${ }^{3}$ This has led to increasing interest in the use of alternative disinfectants. ${ }^{5}$ Furthermore, to

Corresponding author

Phone : +82-(0)2-970-6691 Fax : +82-(0)2-973-9149

E-mail : suwyoung@snut.ac.kr 
protect human health and the environment, the residual concentration of $\mathrm{ClO}_{2}$ must be below $1 \mathrm{mg} / \mathrm{L}$ in treated water. ${ }^{5}$ Therefore, a highly sensitive and selective method for the determination of $\mathrm{ClO}_{2}$ is required. ${ }^{5}$

Due to its toxicity, many analytical methods have been established such as gas-liquid chemiluminescence of the luminal chlorine system, ${ }^{6}$ the use of an amperometric sensor, ${ }^{2}$ capillary electrophoresis, ${ }^{7}$ PDMS microchip electrophoresis, ${ }^{3}$ chip based isotachophoresis, ${ }^{8}$ gas chromatography mass spectrometry, ${ }^{4}$ capillary online concentration coupled with flow injection analysis, ${ }^{5}$ the use of semiconductor chemical sensors, ${ }^{9}$ and flow injection spectrophotometry. ${ }^{10}$ These spectro and electro techniques are complicated and expensive. However, voltammetry is easy to use and inexpensive. For example, a $\mathrm{CaMg}_{3}\left(\mathrm{SiO}_{3}\right)_{4}$-doped $\mathrm{CdS}$ electrode, ${ }^{1}$ a graphite electrode, ${ }^{11}$ and multi-walled carbon nanotubes $^{12}$ are used for there purpose. Some of these electrodes approached to sensitive analytical detection ranges but do not have low detection limit, as was the case with the used device.

In this paper, a metal gold and carbon nanotube working sensors were compared, where gold metals are commonly used in sensor techniques, such as benzyl dimethyl phenyl ammonium chloride, ${ }^{13}$ trace lead, cadmium, ${ }^{14}$ bismuth, ${ }^{15}$ and nucleic acids ${ }^{16}$ detections. Under optimum condition, gold AE shows sensitive catalytic current then carbon nanotube electrode. Moreover a simple graphite reference and a counter electrode was used instead of complicated reference $\mathrm{Ag} / \mathrm{AgCl}$ and $\mathrm{pt}$ counter, which developed methods can be usable for waters controlling

\section{Experimental Procedure}

\subsection{Preparation of the electrodes}

Two types of electrodes were compared at the CV conditions of $-2.0 \mathrm{~V}$ initial potential, and $2.0 \mathrm{~V}$ switching potential using $500 \mathrm{mv} / \mathrm{Sec}$ scan rate. The CNTE working sensor was made with a nanotube and mineral oil (50:50 Wt \%). The mixed paste was homogenized in a mortar for 30 minutes and inserted in a $0.3 \mathrm{~mm}$-diameter glass tube. The $\mathrm{AE}$ electrode was made with a pure gold metal wire with a $0.3 \mathrm{~mm}$ diameter. $\mathrm{An} \mathrm{Ag} / \mathrm{AgCl}$ electrode and a platinum wire electrode served as the reference electrode and the auxiliary electrode, respectively. A three-electrode cell was used to measure with the voltammetric signal.

\subsection{Reagents}

All the experimental solutions were prepared from $18 \mathrm{M} \mathrm{ohm} \mathrm{cm}^{-1}$ double-distilled water and a standard grade reagent. A $0.1 \mathrm{M} \mathrm{NaClO}$ standard solution, with a $\mathrm{pH}$ value of 4.75 served as the supporting electrolyte solution. All the systems were carried out in dissolved oxygen, and an electrode cleaning time was not necessary for each measurement. The phosphoric acid solution was found to be the most suitable medium.

\subsection{Experimental procedure}

The common parameter for $\mathrm{CV}$ was a scan rate of $100 \mathrm{mV} / \mathrm{s}$, and the common parameters for SWSV were set at optimized conditions. CNTE stabilization was performed through a cyclic scan with an initial potential of $+2.0 \mathrm{~V}$, a switching potential of $2.0 \mathrm{~V}$, and a scan rate of $0.5 \mathrm{mV} / \mathrm{s}$, with a stabilized ten cyclic repeat, for the paste surface. Since the voltammetric response of $\mathrm{Cl}$ is dependent on the electrolyte solutions and the hydrogen ionic strength, various types of electrolyte solutions were tested. The phosphate solution yielded the best results.

\section{Results and Discussion}

Under cyclic conditions, both electrodes were compared with AE and CNTE. Fig. 1(A) shows the voltammograms of the concentration effects. The large pictures in the figure show the $\mathrm{CV}$ results of $\mathrm{AE}$ in the concentration range from 1 to $9 \mathrm{mg} / \mathrm{L}$ spike. The first peak current reached $18.16 \times 10^{-6} \mathrm{~A}$ at $\mathrm{Cl}(\mathrm{I})$ spike of below $1 \mathrm{ppm}$, then of $34.57,50.25$, 64.12, 77.21, 91.72, and $105.7 \times 10^{-6} \mathrm{~A}$ appeared with increasing concentration ranging from $2-7 \mathrm{ppm}$ spike. The inset shows the results for CNTE. The peak current went up to $2.09 \times 10^{-6} \mathrm{~A}$ when $1 \mathrm{ppm}$ of $\mathrm{Cl}$ was spiked. It went up to 9.72, 64.31, 148.5, 231.3, 


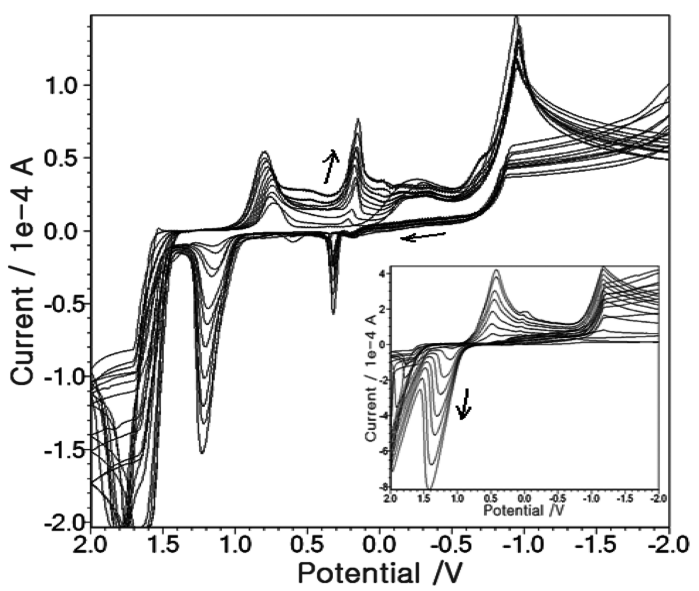

(a)

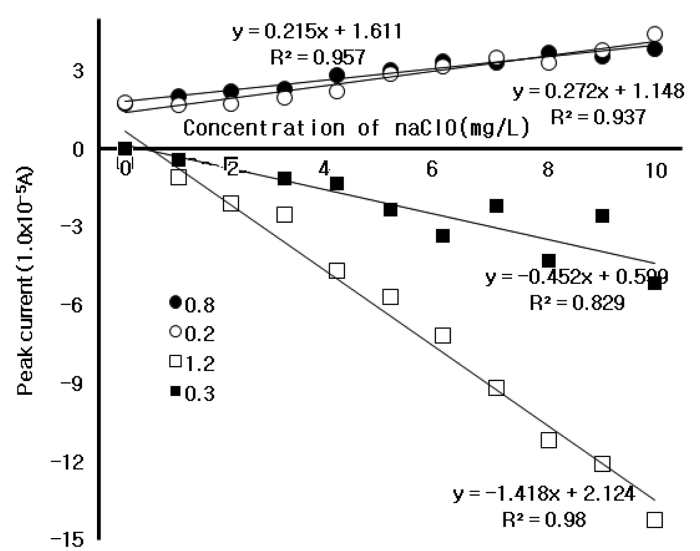

(b)

Fig. 1. (A) The CV results of $\mathrm{AE}$ and CNTE (inset curve) at the range from 1-9 $\mathrm{mg} / \mathrm{L} \mathrm{Cl}(\mathrm{I})$ add. (B): The working ranges of $\mathrm{AE}$ using optimum parameters.

328.7, 406.9, 524.2, and $615.7 \times 10^{-6}$ A when 2,3 , 4, $5,6,7,8$, and 9 ppm were spiked, respectively. The peak shape of AE was narrower and sharp. Here it was found that $\mathrm{AE}$ could detect $\mathrm{Cl}(\mathrm{I})$ more sensitive than CNTE. Therefore, AE was chosen as the working electrode. Under optimum parameters, the peak potential appeared in the reduction scan of -0.8 and $0.4 \mathrm{~V}$. On the other hand, two peaks appeared in the oxidation scan of $-0.2 \mathrm{~V}$. The inset curve shows the results of CNTE, which are the same as those of AE.

Fig. 1(B) shows the results of the working curves using the AE in Fig. 1(A). The least square fit of each data was $\mathrm{y}=0.215 \mathrm{x}+1.611, \mathrm{y}=0.272 \mathrm{x}+1.148, \mathrm{y}=$ $-0.452 x+0.599$, and $y=-1.418 x+0.599$ with correlation coefficients of $\mathrm{R}^{2}=0.957,0.937,0.829$ and 0.98 Sine. The sensitivity of the reduction peak was low, the oxidation peak based on the SW optimum conditions was used.

\subsection{SW optimizations of $\mathrm{AU}$}

Fig. 2(A) shows the SW results in the range of 1-9 $\mathrm{mg} / \mathrm{L}$ spike using AE. When $1 \mathrm{mg} / \mathrm{L}$ was spiked, the peak current obtained to 5.75. Then 2, 3, 4, 5, 6, 7, 8, and $9 \mathrm{ppm}$ were spiked, there peak current increased to 15.97, 23.81, 24.54, 31.12, 39.95, 31.75, 34.39, and $55.08 \times 10^{-7}$, respectively. Fig. 2(B) shows the peak current as a function of potential at various $\mathrm{SW}$ amplitudes in the range of 0.005-0.05 V. When a $0.005 \mathrm{~V}$, amplitude was given, the stripping peak current of $\mathrm{AE}$ reached $0.263 \times 10^{-5} \mathrm{~A}$. When 0.01 , $0.025,0.03,0.04$, and $0.05 \mathrm{~V}$ were applied, the stripping peak current of AE became 0.559, 1.509, $1.726,2.285$, and $2.632 \times 10^{-5}$, respectively. Therefore, $0.05 \mathrm{~V}$ was chosen as the optimized condition of amplitude. Fig. 2(C) shows the voltammograms by the frequency variations in the range of 5-45 V. When $5 \mathrm{~Hz}$ was given, the stripping peak current reached $0.919 \times 10^{-5}$. When $10,15,20,25,30,35,40$, and $45 \mathrm{~Hz}$ were given, the stripping peak current became 1.137, 1.334, 1.308, 1.435, 1.56, 1.601, 1.658, and $1.719 \times 10^{-5} \mathrm{~A}$, respectively. The $45 \mathrm{~Hz}$ was chosen as the optimized condition of frequency. Under this condition, Fig. 2(D) shows various SW accumulation time variations in the range of $0-180 \mathrm{~s}$. When $0 \mathrm{~s}$ was given, the peak current reached $1.715 \times 10^{-5} \mathrm{~A}$. When $30,60,90,120,150$, and $180 \mathrm{~s}$ were given, the peak became $1.752,1.715,2.907,2.847,2.661$, and $2.375 \times 10^{-5} \mathrm{~A}$, respectively. As a result, $90 \mathrm{~s}$ was chosen as the optimized condition of the accumulation time. Under those condition, stripping parameters of the SW final potential, the SW initial potential, the SW incremental potential, and the electrolyte hydrogen ionic strength were examined (data not shown). And the analytical working ranges were examined.

\subsection{Analytical working range and statistic}

Using with $0.4 \mathrm{~V}$ accumulation potential, $1.5 \mathrm{~V}$ switching potential and $90 \mathrm{~s}$ accumulation time, 


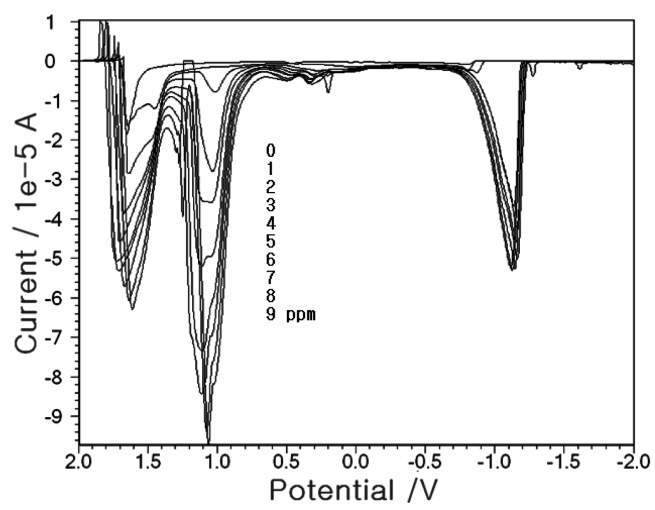

(a)

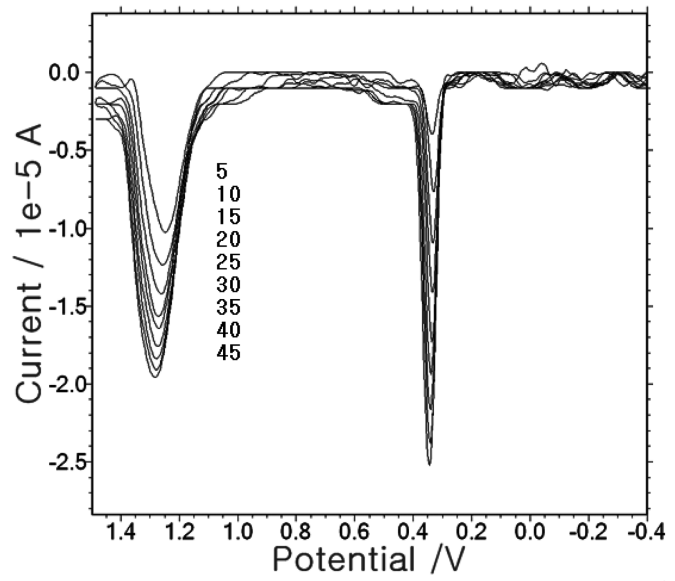

(c)

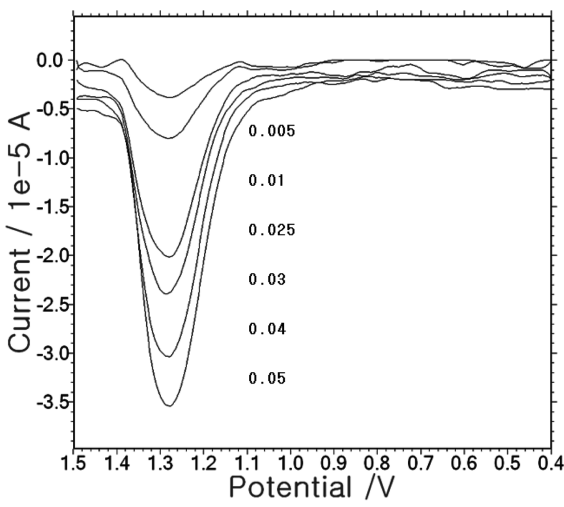

(b)

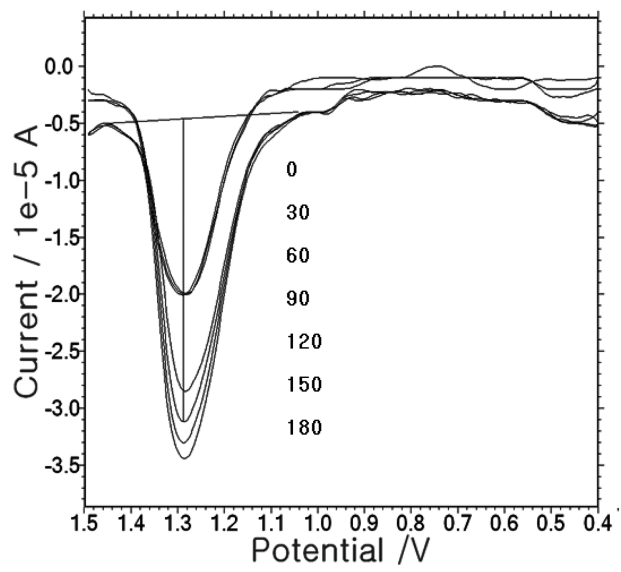

(d)

Fig. 2. (A) The $\mathrm{SW}$ results using $\mathrm{AE}$ in the range of $1-9 \mathrm{mg} / \mathrm{L} \mathrm{Cl}(\mathrm{I})$ variation. (B) Variations of the $\mathrm{SW}$ amplitude in the variation range of $0.005-0.05 \mathrm{~V}$. (C) The $\mathrm{SW}$ frequency in variations of $0-400 \mathrm{~Hz}$. (D) The accumulation time in the range of 30-180 s. Under $10 \mathrm{mg} / \mathrm{L} \mathrm{Cl(I)} \mathrm{add.}$

analytical SW and CV working ranges were examined. Their results were compared with those of commercial RC meters. Fig. 3(A) shows the SW voltammograms in the range of $0.01-0.08 \mathrm{mg} / \mathrm{L} \mathrm{Cl}(\mathrm{I})$ add. When 0.01 $\mathrm{mg} / \mathrm{L} \mathrm{Cl}$ was spiked, the peak current reached $3.06 \times 10^{-6} \mathrm{~A}$. When $0.02,0.03,0.04,0.05,0.06,0.07$, and $0.08 \mathrm{mg} / \mathrm{L}$ were spiked, the peak current increased to $1.93,2.63,3.27,3.84,4.43,4.94$, and $5.41 \times 10^{-6}$ A. Also Fig. 3(B) shows the CV results based on the optimum condition in the range of 1-10 $\mathrm{mg} / \mathrm{L}$ spike. The peak current reached $2.884 \times 10^{-6} \mathrm{~A}$ when $1 \mathrm{mg} / \mathrm{L}$ was put. It went up to $3.494,3.927$, $4.468,5.059,5.853,6.672,7.523,8.058$, and $9.161 \times 10^{-6}$ A when $2,3,4,5,6,7,8,9$, and $10 \mathrm{mg} / \mathrm{L}$ were put. These two figures show that the device that was used is very sensitive. It can also detect low concentrations of $\mathrm{Cl}$. Fig. 3(C) compares the two devices: the device used, and the RC commercial analyzer.

The linear equation for developed SW was $\mathrm{y}=$ $1.085 \mathrm{x}-0.245$, and the precision was $\mathrm{R}^{2}=0.996$. Also the linear equation for $\mathrm{CV}$ was $\mathrm{y}=0.674 \mathrm{x}+1.352$, and the precision was $\mathrm{R}^{2}=0.989$. Then the linear equation for the $\mathrm{RC}$ meter was $\mathrm{y}=0.626 \mathrm{x}-0.601$, and the precision was $\mathrm{R}^{2}=0.998$. Here the developed method can be used to detect $\mathrm{Cl}(\mathrm{I})$ in tap water. The CV slop is similar to the graph of the RC meter. The SW graph, however, was significant slop and sharp. The working curve of the used device is longer and attained a lower detection limit than did the RC 


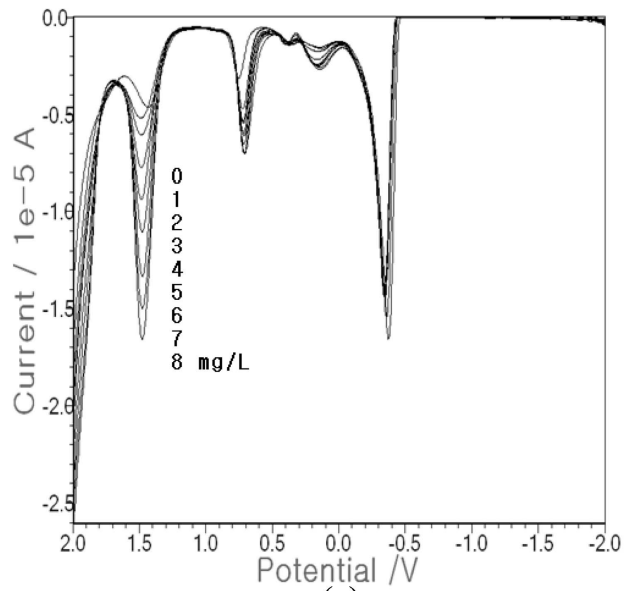

(a)

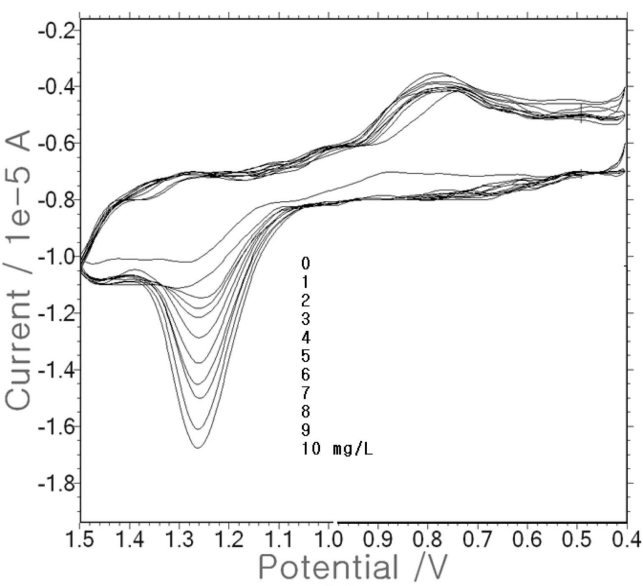

(b)

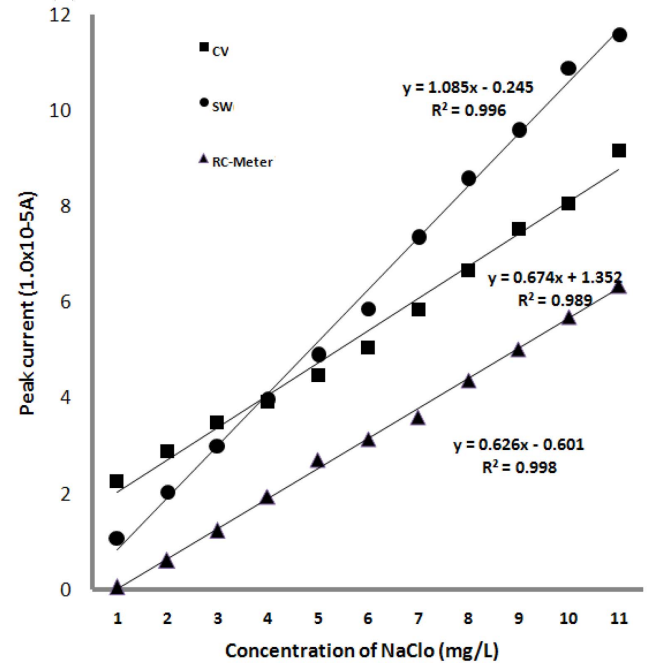

(c)

Fig. 3. (A) Analytical working ranges of $0.01,0.02,0.03,0.04,0.05,0.06,0.07$, and $0.08 \mathrm{mgL}^{-1} \mathrm{Cl}$ ion spiked using SW. (B) Working ranges of $1,2,3,4,5,6,7,8,9$, and $10 \mathrm{mLL}^{-1}$ spiked using CV. (C) Comparison of SW, CV, and the use of the commercial $\mathrm{RC}$ meter.

meter (not shown here).

\section{Conclusion}

The optimal conditions for $\mathrm{AE}$ were found to be at a $0.05 \mathrm{~V}$ SW amplitude, $45 \mathrm{~Hz}$ frequency, $0.4 \mathrm{~V}$ initial potential, $1.5 \mathrm{~V}$ final potential, and $90 \mathrm{~s}$ accumulation time. Two devices were compared based on these conditions-the RC meter and the used device. After the comparison, it was found that the used device more sensitively and minutely perceived $\mathrm{Cl}(\mathrm{I})$ than did the $\mathrm{RC}$ meter. It detected $\mathrm{Cl}$ ion to the range of $0.1-1 \mathrm{mg} / \mathrm{L}$. On the other hand, the results of the used device approximated a very low range and reached lower detection limits than did the common method. It turned out that the used device much more sensitively perceives $\mathrm{Cl}$.

\section{References}

1. X. Liang, F. Liu, T. Zhong, B. Wang, B. Quan and G. Lu. Solid. State. Ionics., 179, 1636 (2008).

2. L. Trnkova, V. Adam, J. Hubalek, P. Babula and R. Kizek, Sensors 2008, 8, 5619 (2008). 
3. X. A. Li, D. M. Zhou, J. J. Xu and H. Y. Chen, Talanta, 75, 157 (2008).

4. H. S. Shin and D. G. Jung, J. Chromatogr. A, 1123, 92 (2006).

5. G. Jin, J. Yang and J. F. Li, Microchim. Acta, 148, 171 (2004).

6. Z. X. Gao, H. F. Li, J. Liu and J. M. Lin, Anal. Chim. Acta, 622, 143 (2008).

7. E. V. Polyakova and O. V. Shuvaeva, J. Anal. Chem., 63, 391 (2008).

8. J. E. Presta, M. S. Beardahb, S. J. Baldocka, S. P. Doyleb, P. R. Fieldena, N. J. Goddarda and B. J. T. Browna, J. Chromatogr. A, 1195, 157 (2008).

9. T. V. Belysheva and L. P. Bogovtseva, J. Anal Chem., 61, 494 (2006).
10. B. Saad, W. T. Wai, S. Jab, W. S. W. Ngah, M. I. Saleh and J. M. Slater, Anal. Chim. Acta, 537, 197 (2005).

11. G. Pezzatini, I. Midili, G. T. F. Loglio and M. Innocenti, Anal. Bioanal. Chem., 380, 650 (2004).

12. G. Sun, S. Liu, K. Hua, X. Lv, L. Huang and Y. Wang, Electrochem. Commun., 9, 2436 (2007).

13. A. Fanigliulo and B. Bozzini, Electrochim Acta 47, 4511 (2002).

14. Y. Bonfil, M. Brand and E. Kirowa-Eisner, Anal. Chim. Acta, 464, 99 (2002).

15. L. Baldrianova, I. Svancara, M. Vlcek, A. Economouc and S. Sotiropoulos, Electrochim. Acta, 52, 481 (2006).

16. G. Carpini, F. Lucarelli, G. Marrazza and M. Mascini, Biosens Bioelectron., 20, 167 (2004). 